Article History:

Received: July 7, 2020

Revised: August 12, 2020

Accepted: August 24, 2020 https://doi.org/10.3126/pycnjm.v13i1.31494

PYC Nepal Journal of Management

Vol. XIII, No. 1, Page: 33-39

\title{
Accounting Practices of Small and Medium Sized Manufacturing Enterprises (SMEs) in Nepalgunj Industrial District
}

\author{
Naba Raj Adhikari'
}

\begin{abstract}
The study aims to examine current status of accounting practices in Nepalese small and medium sized manufacturing firms, basing the study on the primary data followed by survey research method. The study concentrated on 18 firms out of 30 manufacturing SMEs as the study area, located in Nepalgunj industrial district. Through self-designed questionnaire comprised into five point Linkert scale, data was collected from managers, owners, and accounting officers of SMEs. The findings revealed that majority of SMEs have been following manual accounting system, and also have been internally preparing their financial accounting statements from accounting experts. In terms of maintaining accounting information, the study reached a conclusion that tax assessment and business performance are key motivational factors. Traditional accounting indicators have got the highest usage, and also viewed as the most usefulness for performance measurement. This study provides more understanding on the accounting practices of manufacturing SMEs that can be used for further research regarding accounting practices in cross industrial district as well as cross country comparisons to provide rich information.
\end{abstract}

Key words: Small and medium sized enterprises (SMEs); Manufacturing firms; Accounting practices; Financial information.

\section{INTRODUCTION}

Small and medium sized enterprises (SMEs) occupy important roles in the economic growth and sustainable development, especially in the developed and developing

1. Mr. Adhikari is an Associate Professor at Central Department of Management, Tribhuvan University, Nepal. He can be reached at adhikarinavaraj7@gmail.com 
countries (Longenecker et al., 2008; Ahmad, 2012). However the diversity of businesses in the world have created disadvantages to the SMEs capabilities in order to sustain their competitive advantages (Marriott \& Marriott, 2000). Typical accounting functions can play an important role in businesses to maintain competitive advantages. However, some of the small and medium sized enterprises (SMEs) have faced problems in handling their accounting functions due to the lack of expertise on accounting functions (Everaert et al., 2006). The International Accounting Standards Committee Foundation (IASCF, 2007) defines a SMEs as an entity that does not have public accountability and thus publishes general purpose financial statements for external users. SMEs are entities which do not have the onerous requirement of filing their financial statements with any regulatory body for the purpose of issuing financial instruments. Sian and Roberts (2006) defined microentities as the smallest entities within the SMEs spectrum and that these entities have less than 10 employees (including those that do not have any employees).

Accounting system provides a source of information to the owners and managers of SMEs for the measurement of their financial performance. The importance of accounting indicators (measures) for performance measurement to any business entity, big or small, cannot be over-emphasized. Mitchell et al. (2000) expressed that accounting information could help SMEs to manage short-term problems in areas such as costing, expenditure and cash flow by providing information to support monitoring and control. United Nations Conference on Trade and Development [UNCTD, 2000) found that generally, many SMEs do not keep proper financial records and accounts as they are not aware or convinced of the usefulness of accounting and financial reporting requirements for control and decisionmaking purpose. Ismail (2009) identified that SMEs are lacking accounting knowledge and support to perform accounting functions thus they are more likely to outsource their accounting works to accounting firms. Perren \& Grant (2000), highlighted that the SMEs actually relied on sufficient accounting information, including managerial accounting, which was often acquired via informal means, to make their business decisions.

Despite the variations on the use of accounting information among small businesses, there is evidence to suggest that small firms are aware of the importance of accounting information and used it for a variety of purposes (International Federation of Accountants, 2006). It has been recognized that appropriate accounting information is important for a successful management of any business entity, whether large or small (European Commission, Enterprise and Industry Directorate-General, 2008). Industrial policy-2010 has categorized Nepalese industries as micro, cottage, small, and large industries. SMEs have comparatively more contributions in employment and in economic development than large scale industries in Nepal (Kharti, 2019). Majority of the Nepalese SMEs prepare their accounting reports at least one time in a year and among the financial accounting reports the statement of profit and loss was considered as most useful, followed by balance sheet and cash flow (Sharma, 2015). SMEs need to be aware and convinced of the usefulness of accounting information for better management control and decision-making purposes in order to access new markets and maximize their profits in the corporate world (Jayabalan et al., 2009). Maseko \& Manyani (2011) identified 
that SMEs do not keep complete accounting records because of lack of accounting knowledge and as a result there is inefficient use of accounting information in financial performance measurement. Furthermore, the study of (Ankrah, et.al., 2015) found that majority of small scale enterprises do not employ the services of a full time account staff to help carry out the accounting duties due to high cost of hiring an accountant. The appropriate accounting practices by Nepalese manufacturing SMEs may supply complete and relevant financial information needed to improve economic decisions made by entrepreneurs. In this context the study aims:

- To examine current status of accounting practices in Nepalese small and medium sized manufacturing firms.

- To identify the motivation (purpose) for maintaining accounting information.

- To analyze the use and usefulness of accounting indicators for performance measurement.

\section{METHODOLOGY AND RESULTS}

This study is based on descriptive and explanatory research design. A total of 30 small and medium sized manufacturing firms, which were under operation during the last quarter of 2019, in Nepalgunj industrial district was considered as the population of the study. Out of the 30 firms under the population, only 18 firms were selected as the sample for the study through purposive and convenience sampling technique based on characteristics of a population and the objective of the study. The researcher used survey method to collect primary data from the respondents comprised with five point Likert scale. Information for the study was collected from managers, proprietors and accounting officials of SMEs through self-designed survey covering the different variables recognized in the literature. The items in the questionnaire were developed having accounting indicators; 1 low used and 5 for highest used, and in respect of usefulness, 1 for less important and 5 for most important. Cronbach's alpha was determined to measure the internal consistency (reliability) having the estimation of 0.837 . Out of the all out of 32 distributed questionnaires, only 30 complete questionnaires were returned and acknowledged for the purpose of data analysis. Descriptive statistics was applied for the analysis of relevant information assembled through survey.

Table 1

Operation of accounting system by SMEs

\begin{tabular}{lc}
\hline Nature of operation & Percentage (\%) \\
\hline Manual & 63.52 \\
Mechanical (Computerized) & 36.48 \\
Total & 100.00 \\
\hline
\end{tabular}

Table 1 presents the operational nature of accounting system followed by the SMEs. The findings of the current study show that majority (63.52 percentage) firms have practiced manual system while 36.48 percentage firms have followed computerized 
system. It indicates that operation of accounting through manual system has got high preference than the computerized system in SMEs.

The data presented in Table 2 reveals that majority (62.35 percentage) of the SMEs prepare their accounting statements internally by accounting expertise. In contrary 16.33 percentage firms have practiced externally. Moreover the preparation of statements through computerized accounting system (11.60 percentage) and internally with outside advisor (9.72 percentage) reveal low adoption rates.

Table 2

Preparation of accounting statements by SMEs

\begin{tabular}{lc}
\hline Preparation of accounting statements & Percentage (\%) \\
\hline Internally by accounting expertise & 62.35 \\
Internally with outside advisor & 9.72 \\
Externally prepared & 16.33 \\
Prepared by computerized accounting system & 11.60 \\
Total & 100.00 \\
\hline
\end{tabular}

Table 3 highlights the motivation (purpose) of maintaining accounting information. The results indicates that tax assessment (mean value $=4.476$ ) and measure business growth or performance (mean value $=4.269$ ) have considered key motivational factor for maintaining according information. Likewise the assessment of profitability and other financial status (mean value $=3.923$ ) as well as planning for future operations (mean value $=3.615$ ) have got moderate importance on maintaining accounting information. Controlling overheads cost, capital budgeting decision and pricing decision (mean value $<3.000$ ) revealed low motivational factor.

Table 3

\section{Motivation towards maintaining accounting information}

\begin{tabular}{llc}
\hline Motivation for maintaining information & Mean & SD \\
\hline Assess the profitability and other financial status & 3.923 & 0.627 \\
For capital budgeting decision & 2.615 & 0.537 \\
For controlling overheads cost & 2.513 & 0.581 \\
For the sole purpose of tax assessment & 4.476 & 0.503 \\
For pricing decision & 2.576 & 0.503 \\
Measure business growth or performance & 4.269 & 0.452 \\
Planning future operations & 3.615 & 0.637 \\
\hline
\end{tabular}

The data reported in Table 4 shows the importance of accounting statements perceived by SMEs. The statement of profit and loss and cash flow statement have perceived crucial accounting statements accordingly ranked on 1 and 2. Moreover balance sheet, bank statement, break even analysis and financial ratio analysis have ranked on 3, 4, 5 and 6 respectively. The other accounting statements (mean value < 3.00 mean value) have perceived less importance by the SMEs. 
Table 4

Level of importance of accounting statements prepared by SMEs

\begin{tabular}{lccc}
\hline Accounting statements & Mean & SD & Rank \\
\hline Balance sheet & 3.684 & 0.496 & 3 \\
Bank statement & 3.672 & 0.788 & 4 \\
Break even analysis & 3.615 & 0.697 & 5 \\
Cost-volume-profit analysis & 2.461 & 0.508 & 9 \\
Financial forecasting and budgeting & 2.961 & 0.527 & 7 \\
Financial ratio analysis & 3.230 & 0.429 & 6 \\
Published industries information and trends & 1.192 & 0.689 & 12 \\
Statement of cash flow & 4.038 & 0.720 & 2 \\
Statement of change in financial position & 1.538 & 0.508 & 11 \\
Statement of cost & 2.895 & 0.516 & 8 \\
Statement of Profit and Loss & 4.654 & 0.485 & 1 \\
Value added statement & 1.875 & 0.797 & 10 \\
\hline
\end{tabular}

Table 5 reflects the usage and usefulness of financial accounting indicators in SMEs. The indicators like net profit (mean value $=4.807$ ), sales (mean value $=4.653$ ), growth rate of sales (mean value $=4.538$ ) and cash flow (mean value $=4.346$ ) have got highest usage to evaluate the financial performance. However earning per share ( mean value $=2.692$ ) and return on equity (mean value $=2.769$ ) are minimally used. The other indicators (mean value 3.115 to 3.693 ) are moderately used. In respect with the usefulness of performance measures, net profit (mean value $=4.615$ ), sales (mean value $=4.461$ ), growth rate of sales (mean value $=4.451$ ) and cash flow (mean value $=4.154$ ) are viewed as most important indicators. On the other hand, inventory level, return on equity and earning per share having mean value $<3.000$ are considered as less important.

Table 5

Usage and usefulness of financial accounting indicators

\begin{tabular}{lccllllll}
\hline \multirow{2}{*}{ Accounting indicators } & \multicolumn{3}{c}{ Usage } & & \multicolumn{3}{c}{ Usefulness } \\
\cline { 2 - 3 } & Mean & SD & Level & & Mean & SD & Level \\
\hline Break-even sales & 3.269 & 0.603 & High & & 3.769 & & 0.710 & Important \\
Cash flow & 4.346 & 0.689 & Highest & & 4.154 & 0.784 & Most important \\
Earnings per share & 2.692 & 0.471 & Low & & 2.706 & 0.633 & Less important \\
Gross profit & 3.539 & 0.646 & High & & 3.808 & 0.895 & Important \\
Growth rate of sales & 4.538 & 0.581 & Highest & & 4.451 & 0.581 & Most important \\
Inventory levels & 3.115 & 0.711 & High & & 2.769 & 0.651 & Less important \\
Net profit & 4.807 & 0.491 & Highest & & 4.615 & 0.571 & Most important \\
Operating profit & 3.846 & 0.967 & High & & 3.646 & 0.628 & Important \\
Return on assets & 3.231 & 0.863 & High & & 3.576 & 0.504 & Important \\
Return on equity & 2.769 & 0.815 & Low & & 2.657 & 0.735 & Less important \\
Return on investment & 3.693 & 0.710 & High & & 3.311 & 0.617 & Important \\
Sales & 4.653 & 0.629 & Highest & & 4.461 & 0.706 & Most important \\
Value added & 3.384 & 0.496 & High & & 3.115 & 0.908 & Important \\
\hline
\end{tabular}




\section{CONCLUSION}

The study has primarily sought to examine the accounting practices of manufacturing SMEs in Nepal. Questionnaires were distributed to managers, owners, and accounting officers of SMEs. A total 30 complete questionnaires were returned and acknowledged for the purpose of data analysis. After the observation and analysis of collected data, the results have shown that most of the enterprises have been following the manual accounting system. The field survey findings indicated the majority of SMEs have internally prepared their financial accounting statements from accounting experts. The study has also discovered that tax assessment and measuring business performance are the key motivational factors for maintaining accounting information. In contrast, controlling overhead costs, capital budgeting decision, and pricing decision are considered as low motivational factors. The research found that the traditional statements i.e. profit and loss, and cash flow statement have perceived as crucial accounting statements. These findings are in line with the results of similar surveys (Sharma, 2015; Maseko \& Manyani, 2011). Furthermore, the traditional accounting indicators have got the highest usage, and also viewed as the most usefulness for performance measurement. The study, contributes to current knowledge in accounting practices of manufacturing SMEs in Nepal. In future, the findings of this survey could be compared and used for further research regarding accounting practices in cross industrial district SMEs in Nepal as well as cross country SMEs.

\section{REFERENCES}

Ahmad, S. Z. (2012). Micro, small and medium-sized enterprises development in the Kingdom of Saudi Arabia: Problems and constraints. World Journal of Entrepreneurship, Management and Sustainable Development, 8(4), 217- 232.

Ankrah, E., Mensah, C. C. Y., \& Ofori-Atta, K. (2015). The relevance of accounting information in the management of small scale businesses in the Yilo Krobo District in Ghana. European Journal of Business and Management, 7(8), 181-189.

European Commission, Enterprise and Industry Directorate-General (2008). Final Report of the Expert Group: Accounting System for small enterprises - Recommendations and good Practices. November 2008.

Everaert, P., Sarens, G., \& Rommel, J. (2006). Sourcing of accounting: Evidence from Belgian SMEs. Working Paper. Ghent University, Belgium. http://www.WP/Papers/wp06 403.pdf

International Accounting Standards Committee Foundation (IASCF 2007). Exposure draft of a proposed IFRS for SMEs. February 2007. IASC Foundation Pubs. London.

International Federation of Accountants (2006). Micro-entity financial reporting: Perspectives of preparers and users, Small and Medium Practices Committee, International Federation of Accountants, New York.

Ismail, N.A. (2009). Factors influencing AIS effectiveness among manufacturing SMEs: Evidence from Malaysia. The Electronic Journal of Information System in Developing Countries, 38(10), 1-19.

Jayabalan, J., Dorasamy, M., Raman, M., \& Ching Ching, N.K. (2009). Outsourcing of accounting functions amongst SME Companies in Malaysia: An Exploratory Study. Accountancy Business and the Public Interest, 8(2), 96-114. 
Khatri, M. B. (2019). Small and medium scale enterprises and their role in employment generation in Nepal. Tribhuvan University Journal, 33(1), 129-140.

Longenecker, J.G., Moore, C.W., Petty, J.W., \& Palich, L.E. (2008). Small Business ManagementLaunching and Growing Entrepreneurial Ventures. 14th Edition, Thomson South-Western, Mason.

Marriott, N., \& Marriott, P. (2000). Professional accountants and the development of a management accounting service for the small firm: barriers and possibilities. Management Accounting Research, 11(4), 475-492.

Maseko, N., \& Manyani, O. (2011). Accounting practices of SMEs in Zimbabwe. Journal of Accounting and Taxation, 3(8), 171-181.

Ministry of Industry. (2010). Industrial policy 2010. Kathmandu: Government of Nepal.

Mitchell, F., Reid, G., \& Smith, J. (2000). Information system development in the small firm: The use of management accounting, CIMA Publishing, United Kingdom.

Perren, L., \& Grant, P. (2000). The evolution of management accounting routines in small businesses: A social constructive perspective. Management Accounting Research, 11(4), 391-411.

Sharma, G. (2015). Practices of financial and management accounting: Evidence from small and medium-sized enterprises of Nepal. The Journal of Nepalese Business Studies, 9(1), 77-86.

Sian, S., \& Roberts, C. (2006). Micro-entity Financial Reporting: Some Empirical Evidence on the Perspectives of Preparers and Users. Paper prepared for Small and Medium-sized Practices Committee. IFAC. NY.

United Nations Conference on Trade and Development [UNCTD] (2000). Trade And Development Report, from http:// unctad.org/en/docs/tdr 2000_en.pdf 